\title{
Harnessing Farmers' Knowledge and Perceptions for Health-Risk Reduction in Wastewater-Irrigated Agriculture
}

\author{
Bernard Keraita, Pay Drechsel, Razak Seidu, Priyanie \\ Amerasinghe, Olufunke O. Cofie and Flemming Konradsen
}

\begin{abstract}
This chapter addresses the importance of understanding farmers' knowledge and perceptions on health-risk and risk-reduction measures for the development of mutually acceptable risk-management strategies. Drawing on studies from different countries, the chapter shows that it is not realistic to expect high risk awareness. In cases where farmers are aware of health risks, they assess mitigation measures in view of their overall impact on work efficiency and crop yield rather than only the potential health benefits to be gained. The chapter asserts that for on-farm risk-reduction measures to be successful, it is pertinent that farmers' needs and constraints are incorporated into the formulation of recommended practices. This might happen through indigenous processes but can be supported through farm-based participatory approaches where farmers and scientists work together in developing risk reduction measures. An important first step is the identification of mutually accepted problem indicators. Where health benefits for farmers and consumers are not sufficient reasons for the adoption of safer practices, other triggers have to be identified as well as appropriate communication channels for effective outreach.
\end{abstract}




\section{INTRODUCTION}

A wide range of measures exists for reducing health risks from wastewater and human excreta use in agriculture. Aside from conventional wastewater treatment, farmers can play a significant role in a multiple-barrier approach. Some of the on-farm measures for health-risk reduction are presented in Chapter 10 of this book. To achieve broad adoption and comprehensive health protection for farmers and consumers, it is necessary that farmers see the risks. Without risk awareness it will be very difficult to promote a behaviour-change towards safer practices. In addition, incentives might be necessary, especially in the fields of health risks where short-term benefits might not be visible, while recommended measures might even require additional resources or reduce crop yields to some extent (see Chapter 16). Soil conservation projects usually face similar challenges (Sanders et al., 1999).

Existing 'standard' recommendations for farm-based risk-management measures can seldom be transferred straight into the farmer's field. Neither drip kits nor recommended cessation periods will automatically fit local conditions, such as cropping density, wastewater quality or crop water requirements. Several technologies require analytical monitoring and evaluation tools far beyond the technical and financial capacities of most farmers, particularly in developing countries. Therefore, it is essential that the development of risk assessments and risk-mitigation measures seeks to involve farmers actively in the process. Ideally, risk-reduction methods and performance assessment should go hand-in-hand so that farmers can see the benefits. This can be best achieved, for example, through mutually agreed indicators. Many studies have shown that farm-based interventions have largely failed due to lack of farmer participation, especially in resource-poor countries (Collinson, 2000; Drechsel and Gyiele, 1998).

Knowledge and awareness of risks strongly influence how risks are perceived and managed (Peres et al., 2006; Stewart-Taylor and Cherries, 1998). Awareness can be based on practical experience, but farmers also incorporate new information and concepts from colleague farmers, agricultural extension officers, field schools, input suppliers, the media, development workers and others into their knowledge base. This chapter reviews knowledge and perceptions of farmers towards wastewaterand human excreta-related health risks from different case studies, with more emphasis on Ghana. It also discusses how this knowledge can be used to influence behaviour-change towards the adoption of health-risk reduction measures.

\section{HEALTH RISKS: FARMERS' PERCEPTIONS AND SCIENTIFIC EVIDENCE}

\section{Wastewater use}

There is overwhelming epidemiological evidence that wastewater and excreta use pose significant health risks if undertaken without effective risk-management 
practices. Several studies show that the greatest risk for farm workers in wastewaterirrigated agriculture derives from intestinal nematode infections and for produce consumers, from bacterial disease infections (Blumenthal and Peasey, 2002; Shuval et al., 1986). However, perception studies show that farmers generally are satisfied with their wastewater sources and do not perceive that wastewater irrigation poses a significant health risk.

Typically, a range of other farming constraints are ranked higher than any health issue and perceived health threats are dominated by ones unrelated to wastewater (Bayrau et al., 2009; Obuobie et al., 2006; Ouedraogo, 2002). Thus, there are often no significant differences in risk perception between farmers using different water qualities as shown in Accra and Ouagadougou (Gbewonyo, 2007; Gerstl, 2001) even where quantitative microbial risk assessments (QMRA) predict gross differences (Seidu et al., 2008). Those farmers who are aware of the potential health risks from using polluted water sources appear to perceive such risks to be low and seem willing to accept these risks because of the economic benefits gained from using polluted water and the unavailability of other water sources (Gbewonyo, 2007; Obuobie et al., 2006). Also, potential risks for consumers are usually questioned although it is difficult to get unbiased answers. Compared with the consumption of wastewater-irrigated food, occupational risks affecting farmers' work performance are ranked higher by farmers (Keraita et al., 2008a, Knudsen et al., 2008). ${ }^{1}$ This awareness, however, seldom translates into the adoption of protective measures (Keraita, 2002; Obuobie et al., 2006). Protective clothing is in most cases perceived to be unsuitable in hot conditions and also not necessary given the low level of perceived risk (Bayrau et al., 2009).

An interesting study was presented by Bayrau et al. (2009), who compared perceived risk between urban farmers using wastewater and rural farmers using clean water. The results showed exactly the opposite of what was expected, and in this way reveals the challenges such perception studies are facing (Table 17.1). The reason in this case, like in many others, is the need to see the farmer in his or her context. The wastewater irrigators were more urban-based, appeared better educated, showed a higher level of hygiene and their housing situation was better

Table 17.1 Prevalence of perceived illness among farmers working on irrigation farms within and around Addis Ababa

\begin{tabular}{lcc}
\hline Perceived illness & \multicolumn{2}{c}{ Prevalence $(\%)^{a}$} \\
\cline { 2 - 3 } & Wastewater area $(\mathrm{n}=240)$ & Freshwater area $(\mathrm{n}=175)$ \\
\hline Intestinal pain & 18 & 51 \\
Diarrhoea & 6 & 49 \\
Skin infection & 0.5 & 4 \\
\hline
\end{tabular}

${ }^{a}$ All differences between both groups were significant at $<1 \%$.

Source: Bayrau et al. (2009) 
in terms of access to piped water, sanitation facilities and number of persons per room (Bayrau et al., 2009).

Studies from Nairobi showed that wastewater farmers were concerned about the quality of their water and its potential to cause disease (Kilelu, 2004). However, farmers' perceptions of the link between wastewater use and enteric diseases were diverse. Some farmers rejected the possibility of negative health consequences due to handling of wastewater or through consuming crops grown with the wastewater and pointed at other food-safety measures, such as cooking. In addition, most farmers indicated that they usually washed their produce before consumption; but the observation by researchers in the field was that produce was consumed without washing. Some felt that they had developed immunity through years of exposure. The farmers' view of enteric disease was that the occurrence of enteric diseases was normal and not necessarily related to their use of wastewater. It is significant that around 80 per cent of the farmers surveyed did not perceive wastewater use to be making them more vulnerable to enteric diseases but enquiry into specific diseases found that the primary health concern for most farmers was skin irritation. Even though farmers were aware of possible negative effects of wastewater on health, they continued to use it as there was no other water available for agriculture.

In Pikine, Senegal, farmers reported malaria, parasitic infection, dermatitis and fatigue as the top four illnesses they had experienced in the previous year. About 70 per cent of the farmers said that they personally had not suffered any illnesses related to wastewater (Chaudhuri, 2008). In comparison, district health statistics in Pikine listed malaria, dermatitis, parasitic infections, arterial hypertension, diarrhoea and anaemia as the top six diseases for all ages. Interestingly, diarrhoea was not cited among the farmers as a health problem, perhaps because of its greater incidence and severity among children. Under-reporting of diarrhoeal episodes may also occur due to cultural taboos because as a loose stool might no longer be perceived as noteworthy.

An earlier study by Niang (2002) found a significantly higher prevalence of Ascaris among wastewater farmers (75 per cent) than farmers using shallow groundwater (21 per cent), while approximately the same number in both groups (46-48 per cent) did not see a relationship with wastewater use. This suggests that many of these farmers may have been infected with parasites without knowing it.

Although this situation draws a pessimistic picture in view of risk awareness, it can change. In the case of Ghana, for example, a number of projects on wastewater and related risk mitigation significantly influenced farmers' knowledge, while different media alerted policy-makers to take action (Obuobie et al., 2006). With or without their own-risk perception, farmers felt the pressure to respond, at least to avoid confrontation and risk losing their business.

The invisibility of pathogens and the lack of connection made between symptoms of potential illnesses and exposure shows the need for mutually agreed risk indicators. While most of the research has been focused on helminth infections and diarrhoeal diseases as occupational health risks in wastewater agriculture, 
more investigation is needed to link skin infections to particular water pollutants (Trang et al., 2007). Studies in Nepal, Cambodia, India, Pakistan and Vietnam have strongly associated skin diseases to contact with untreated wastewater (Keraita et al., 2008b).

\section{HuMAN EXCRETA USE}

Perceptions from farmers using fresh human excreta in southern Ghana are presented in Table 17.2. Farmers asked septic truck drivers to dump their loads on the fields (Cofie et al., 2009). Most farmers associated excreta use with increased agricultural productivity. Bad odour from excreta was mentioned as a major problem by users and also the main reason why non-users were reluctant to use excreta on their lands. Users of excreta perceived that it did not contaminate food as indicated by the high negative index value of -0.93 for users (Table 17.2), which is significantly different from the weighted average index of -0.26 for non-users. However, farmers had good reason for their assessment as, in the study location, excreta is used mainly for maize and not vegetables. After exposure to the sun, dried excreta is ploughed into the soil prior to planting. Nevertheless, out of 11 defined variables that possibly affect farmers' decision to use excreta, only health risk and loss of income emerged as negative influences on the probability of excreta use.

In northern Ghana, where excreta use has a longer tradition, farmers using human excreta associated it with skin infections, diarrhoea, foot rot and vomiting (Seidu et al., 2009). Farmers related vomiting episodes to the strong odour from raw excreta and skin infection to the handling of relatively wet sludge. Dried excreta (cake) and odourless sludge, irrespective of the treatment duration, were on the other hand considered by farmers to pose no health risk. There was no objection to handling these cakes with bare hands including those only dried for a short time. A QMRA of such 'cake sludge' across 40 faecal sludge drying sites in Tamale revealed

Table 17.2 Farmers' perception on the use of human excreta in agriculture

\begin{tabular}{lrcrc}
\hline Factors & $\begin{array}{c}\text { WAl }^{a} \text { of } \\
\text { Users }\end{array}$ & $\begin{array}{c}\text { WAl of } \\
\text { Non-Users }\end{array}$ & T-test & P-value \\
\hline Excreta is good for soil structure & 1.47 & 0.63 & 3.99 & 0.000 \\
Excreta is an important source of nutrients & 1.40 & 0.76 & 3.50 & 0.001 \\
Excreta causes odour problems & 1.50 & 1.60 & 1.04 & 0.302 \\
Excreta poses health risks & 0.50 & 0.70 & 0.20 & 0.839 \\
Excreta is unfriendly to the environment & 0.60 & 0.77 & 0.99 & 0.322 \\
Excreta causes food contamination & -0.93 & -0.26 & 2.49 & 0.042 \\
Excreta deposited on farms has low quality & 0.33 & 0.90 & 3.64 & 0.001 \\
(as perceived through visual appearance) & & & & \\
\hline
\end{tabular}

aWAl = Weighted Average Index.

Source: Cofie et al. (2009) 
high Ascaris and viral infections risk for farmers above the WHO tolerable infection risk of 1 infection per 10,000 persons per year (Seidu et al., 2009).

\section{FACTORS INFLUENCING FARMERS' HEALTH-RISK PERCEPTION}

It is widely expected and accepted that farmers and public health risk experts perceive risks differently (Lazo et al., 2000). Understanding these differences is an important step in the development and promotion of best practices and technologies. What causes these differences and how can they be minimized to enhance adoption of safe practices? In risk-perception studies conducted in Ghana, a number of reasons, including process-related ones, were identified:

\section{Experience of farmers in waste reuse}

Studies show that knowledge and perceptions of farmers on health risks can be influenced by the duration farmers had been involved in their business. In northern Ghana, farmers with a long experience in human excreta application more easily identified diseases to be associated with poorly treated human excreta than those with little experience in its use (Seidu et al., 2009). In Kumasi and Accra, where farmers who had longer experience in wastewater farming generally rated risks lower than those who had been farming for less than two years (Keraita et al., 2008a).

\section{Level of knowledge on risk}

Given the standard educational level among farming communities, most of the farmers did not have deep knowledge about the causes of health problems and health-risk factors. This deficit applies in particular to 'invisible' health risks like pathogens. Training on health risks from wastewater irrigation has not been incorporated in education curricula including those of agricultural extension officers due to the informal nature of this practice and its relatively low national importance. Nevertheless, an increase in knowledge, awareness and interest in health-risk issues and risk mitigation was noticed where farmers were exposed to the issue, mostly through research projects.

\section{Source of knowledge}

Perceptions depend on how people obtain their knowledge. In view of health risks, there are different sources possible, and not all are appropriate. In Ghana, the media has been one of the main sources of knowledge for farmers, which has also shaped a lot of their perceptions on the risk. As observed in other studies, the 
media can build complex messages about risks but can also amplify or attenuate risks (Boholm, 1998); the Ghanaian media, for example, basically condemned the practices and amplified the risks (Obuobie et al., 2006). While complex messages and amplifying risks should be discouraged, risky practices should not be encouraged either. In essence, there should be a balance on presenting risk messages to farmers to ensure that they are rated appropriately to instigate change to safer practices that are necessary for health protection.

\section{Living standards of farmers}

Many farmers live in poor settlement areas under unsanitary conditions, often with limited access to safe drinking water. In such circumstances, the immediate environment influences perceptions forming attitudes and standards with which they live on a day-to-day basis, as also shown in the case reported from Ethiopia (Bayrau et al., 2009). Under these circumstances wastewater irrigation might not receive particular attention. Common standards equally influence researchers, who might have been brought up under different sanitary standards and are now challenged to perform unbiased interviews. Moreover, being exposed to different levels of sanitary standards, both scientists and farmers might have problems in agreeing on common indicators for diseases to be associated with the wastewater or excreta exposure on farm. Detailed epidemiological studies will be necessary to show the fraction attributed to different risk factors.

\section{Defensive strategies}

Interview results might be biased if farmers feel the need to develop defensive strategies to show that their practices are safe so that their business is not jeopardized or so that they are not seen as propagators of public-health risks within the community. Negative perceptions by the interviewer, the public, or harassment from authorities and media, can drive farmers to develop defensive strategies to consciously underestimate health risks associated with their practice. Similar findings have been reported among pesticide users in Brazil (Peres et al., 2006). Such denial and defensive strategies can greatly hinder risk communication and are difficult to separate from low-risk perception associated with living conditions that are unsanitary. It is therefore crucial to build trust among community members and vendors for any risk-factor communication (Siegrist, 2000). This was also shown in a related study done for street-food vending where purchase of street food was mainly based on trust in the vendor, since no reliable indicator existed for actually evaluating food safety. Therefore, trust also becomes a necessity, where no other evaluation parameter is available (Rheinländer et al., 2008).

The opposite of a defensive strategy also occurs where farmers expect external assistance and therefore exaggerate their problems. 


\section{FARMERS' KNOWLEDGE AND PERCEPTIONS OF HEALTH-RISK REDUCTION MEASURES}

Assessing farmer perceptions requires listening skills and unbiased methods. These have to be carefully worked out in different social and cultural settings, by understanding the environment and the access to information that farmers may have. Understanding farmers' knowledge and perceptions on risk-reduction measures, particularly the factors that they use to assess whether technologies are appropriate for them, is very important. This assessment of whether a measure is appropriate does not necessarily consist of an absolute 'yes' or 'no' answer. It usually consists of a ranking of the measures from more appropriate to less appropriate, based on different criteria. Knowing how to garner these perceptions, translate them into criteria for evaluating risk-reduction measures and ranking them against alternative measures is a skill that the researcher has to develop.

In Ghana, wastewater farmers were involved in identifying their own suitable risk-reduction measures (Keraita et al., 2008a), which are presented in Table 17.3. These measures were very different from those suggested in the WHO Guidelines (2006), such as conventional wastewater treatment, crop restrictions, conducting health programmes and human-exposure control. The reason for this was that while WHO's proposed measures are based only on health targets, i.e. the effectiveness of reducing levels of pathogens in irrigation water or on crops, farmers were more concerned with business-related risk factors like loss of yields or income, level of investment (capital, labour, land) needed and land-tenure issues. Generally, farmers preferred only slight changes in their current practices or those which required low investments. Similar findings have been reported in other studies done in resourcepoor communities (Avila and Jabbar, 1992; Marenya and Barrett, 2007) and from participatory on-farm trials in general (Drechsel and Gyiele, 1998; Drechsel et al., 2005). Scientists therefore should address particular risk factors from an integrated multi-risk perspective to be in tune with the farmers' decision-making.

Another important dimension in risk perception studies was highlighted by Knudsen et al. (2008) in a study in Hanoi. The authors showed that the use of protective clothing was gender dependent. More women were found to be wearing protective gloves and boots and with more consistency than men. The differences were mainly attributed to the gender-specific work separation on farm, with men walking around the farms much more than women. Nevertheless, both groups felt that protective clothing constrained their work. These observations have also been made in studies conducted in Ethiopia and Ghana among farmers using wastewater (Bayrau et al., 2009; Obuobie et al., 2006) or human excreta (Seidu et al., 2009). In the Ghana study, which involved 138 vegetable farmers in Accra using wastewater, only 19 per cent wore protective clothing, mainly boots and gloves, while irrigating (Obuobie et al., 2006). In some cases, farmers were found to be wearing protective clothing not because of health risks, but to protect them from cold and physical injuries (Knudsen et al., 2008). 
Table 17.3 Measures identified by farmers to reduce health risks in wastewater irrigation

Measures identified by farmers only

Measures identified following discussions

with scientists

- Provision of safer irrigation water like

- Leaving water in irrigation sources to settle shallow groundwater. and not stepping inside.

- Protection of water sources.

- Treating water with chemicals.

- Filtration of irrigation water.

- Using boots when stepping in water sources.

- Treat soils against pathogens.

- Applying water to roots not on leaves.

- Using right amounts of water.

- Reducing splashing of soils on vegetables.

- Using well-composted manure at the right time.

- Using gloves when applying manure.

- Stopping irrigation days before harvesting.

\section{HEALTH-RISK MANAGEMENT MEASURES USED BY FARMERS}

In general, farmers experiment on their own, responding to perceived production risks like pest attacks, water scarcity or reduced (fertile) land and labour availability (Mutsaers et al., 1997). Among the perceived drivers for change, health risks are not prominent which is not surprising given the low health-risk awareness. Despite this, health-risk reduction measures can become adopted if they are 'sold' well (see Chapter 16, on social marketing) or address more than health concerns; an example is the provision of water-saving drip kits which also avoid pathogen exposure of farmers and crops.

However, low water quality can be a concern to farmers, even if its healthaffecting components are not perceived. This can be wastewater salinity affecting crop performance, high amounts of organic debris and waste blocking tubes, pumps and watering cans, or simply bad odour. Thus, in many cases, farmers have been found to be developing strategies and innovations to adapt to deteriorating water quality in order to maintain or increase yields and reduce other negative trade-offs including health problems. Of particular interest are those innovations which aim at reducing inputs, such as labour while also reducing health risks, like furrow irrigation compared to overhead irrigation with watering cans. This offers an entry point of mutual benefit. The following are a few other examples of farmers' wastewater management practices, in part with direct or indirect impact on health risks:

\section{Hyderabad, India}

Farmers alternate the use of groundwater with wastewater depending on the stage of plant growth. This was found to increase yields and decrease pest attacks on crops and infections among farm workers. Farmers were also found to be shifting 
to more wastewater-tolerant crops, gradually replacing paddy rice with fodder crops that are more tolerant to high salinity levels induced by the wastewater, and still have a high market value.

\section{Dakar, Senegal}

In areas where untreated wastewater has low salinity compared to other water sources in the area, such as on farming sites along coasts, farmers use wastewater to dilute the salinity concentrations in larger depressions and dugouts filled with saline groundwater. This has the simultaneous benefit of diluting other contaminants in the wastewater. This measure, as observed in Pikine, one of the largest urban vegetable farming sites in Dakar, transformed two unsuitable resources into a valuable asset.

\section{Accra, Ghana}

Farmers blocked wastewater channels with a series of sandbags to create ponds from where they could more easily fetch water with cans or pump, simultaneously creating a cascade of worm egg traps and sedimentation ponds, with an obvious impact on pathogen levels (IWMI, 2008).

\section{Dakar, Senegal, and Lomé, Togo}

Farmers fixed mosquito nets over the intake holes of their watering cans to keep debris out. This concomitantly reduced the intake of pathogens attached to floating organic matter, including excreta.

\section{Northern Ghana}

Two sun-drying methods, random spot spreading and pit composting, are used to process raw faecal sludge into odourless 'cake' by farmers. Timing of treatment (drying) is mainly in the dry season when temperatures are high to enhance dewatering of sludge. This is accompanied by the destruction of pathogenic organisms. The duration of drying ranges from a few weeks to several months. In southern Ghana, crops are also irrigated with fresh sludge, i.e. without drying. However, in both cases, the crops are mostly cereals which are cooked before eating. 


\section{IMPLEMENTATION PROCESS TO ENHANCE ADOPTION OF RISK-REDUCTION MEASURES}

Participatory research approaches have shown great potential for facilitating the adoption of innovative risk-reduction measures (Chambers and Ghildyal, 1985; Drechsel and Gyiele, 1998). Participatory research allows for a mutual diagnosis of farmers' constraints and the identification of appropriate solutions within a holistic interdisciplinary framework, rather than a narrow technological or crop focus (Martin and Sherington, 1997). Technology development is based on mutual learning loops and modifications (Figure 17.1). This is particularly important in view of safer irrigation practices, like drip irrigation, furrow irrigation or cessation of water application which can significantly reduce crop yields if not well adapted to local possibilities and constraints (Keraita et al., 2007a,b). The challenge, though, is to find the best compromise between maximum risk mitigation and lowest discomfort for the farmer to minimize possible adoption constraints (Collinson, 2000).

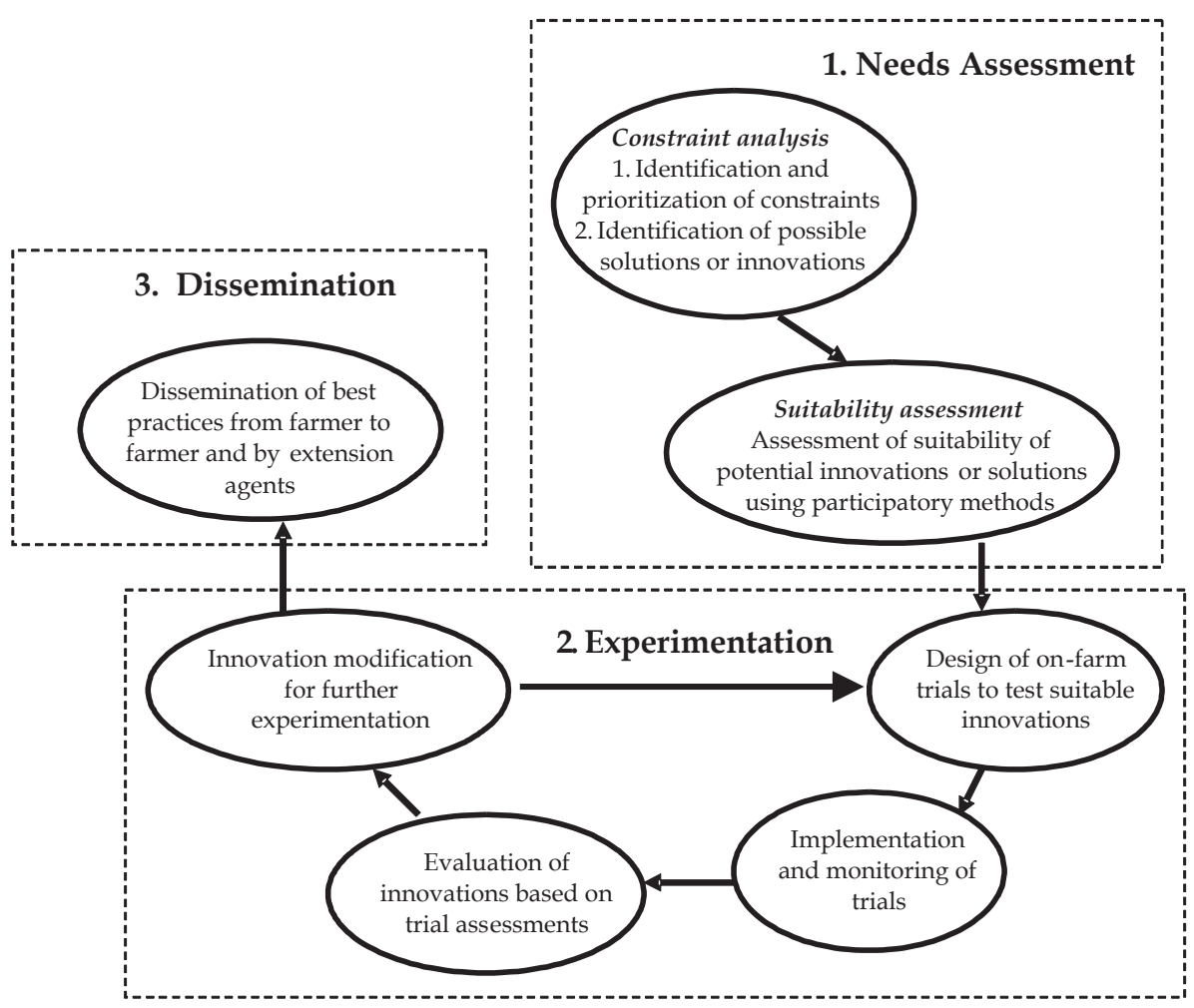

Figure 17.1 Diagrammatic representation of the on-farm research process 


\section{THE CHALLENGE OF VISUALIZING INVISIBLE RISKS}

One of the greatest challenges in safe waste reuse is getting farmers to understand health risks stemming from 'invisible' contamination such as from parasites or chemicals in water and soil. It is also a challenge to get farmers to monitor the effect of reducing invisible risks. As mentioned in Chapter 16, the Ghana handwashing campaign faced a similar challenge but was ultimately very successful. The campaign decided not to provide any information on health risk associated with contaminated hands, but based its message on 'disgust' which appeared to be a sufficiently powerful trigger to protect the family.

Facilitating behaviour-change among farmers, on the other hand, is less straightforward because the main health risks are for consumers far down the market chain. Complaints about the food hardly reach the farmers. There are only very few cases where the farm family also consumes the vegetables that they produce, as exotic vegetables, which are actually those eaten raw, are not common in traditional diets. It is therefore important to study other possible indicators to increase awareness on water pollution and related health risk among farmers.

Low-cost test kits for water-quality monitoring could help to visualize invisible risk, as tested for example in Sri Lanka (Shingles and Saltori, 2008) and Ghana (McGregor et al., 2001). Another possible indicator of pollution could be the lack of certain indicator species such as frogs, toads or insects only known in clean water. Skin rashes might be an indicator of how bad water affects human health. Usually, farmers rely on such physical and sensuous indicators, such as colour, odour and occurrence of solid materials, to ascertain the level of contamination in water. For example, in Kano, Nigeria, some of the farmers, using untreated industrial effluents from breweries and tanneries, use colour, smell and the formation of foam to determine unfavourable or undesirable conditions (Binns et al., 2003). An example of a farmer's statement was:

There are three bad colours [of water] that come at different times. The oily red one and the green one will kill the crops, and when we see these colours in the channel, we turn off our pumps immediately. The bluish water is corrosive and causes a red rash when it comes in contact with the skin. We always wash our hands after we come in contact with the blue water.

Knudsen et al. (2008) similarly illustrated how farmers in peri-urban Hanoi, Vietnam, use locally adapted indicators to characterize wastewater. When the water had pink bubbles, farmers called it 'soap detergent water' and considered it the worst type of water because it had a high content of chemical waste, such as from soap detergent factories. They also described wastewater as 'organic fertilizer water' if the water was black and smelly and associated this water primarily with toilets that discharged directly to the river. 
Participatory on-farm research will allow scientists to verify how far farmers' physical indicators correspond with microbiological reality. For example, studies have shown that although shallow wells used in irrigation had clear water and no bad odour, and were therefore thought to be 'physically clean', they actually contained high levels of coliform bacteria just like water from neighbouring streams that were perceived to be 'physically dirty' (Keraita et al., 2008a). In Tamale, dried 'cake' sludge, considered by farmers to pose no health risk, still had thermotolerant coliform bacteria and Ascaris concentrations above the WHO monitoring guideline for faecal sludge application but, indeed, much lower bacteria levels than fresh sludge (Seidu et al., 2009).

Aside from the agreement on a risk indicator for the water or sludge, the next challenge is to explain to farmers that the recommended (alternative) practices will have a positive impact along the food chain, where other indicators are required to visualize the reduced health risk. An innovative 'germ' indicator, like the Glitterbug ${ }^{\mathrm{TM}}$ gel (www.glitterbug.com), might help to trigger a lasting visual experience which can be applied along the whole farm to fork pathway.

Whatever the indicators might be, they should increase risk awareness and help farmers and scientists to communicate. Increased awareness alone, however, in many cases will not be sufficient to trigger behaviour-change. Additional incentives are needed, such as economic incentives, access to credit or tenure security, and positive media support (Chapter 16). Figure 17.2 shows a comparative assessment of possible triggers mentioned by farmers in Kumasi and Accra versus the ranking of local experts who suggested that farmers might have downplayed their interests in subsidies while overstating their concerns for consumers' health.

\section{COMMUNiCATION CHANNELS}

Participatory approaches among scientists and farmers involved in a project can help with communication, building capacity and finding mutually acceptable solutions. To reach out to even more farmers it is important to know to whom farmers listen and how best to connect with them. A pilot social marketing study in Ghana showed that it is more likely that innovations spread from farmer to farmer through social networks than through any external facilitation (Figure 17.3) and that farmers preferred field demonstration and/or learning by doing (Figure 17.4).

This also verifies the importance of encouraging farmers' own experimentation because it promotes knowledge generation and self-monitoring and evaluation. However, it is pertinent for the implementation process to recognize the wider system within which farmers operate. This system, made up of institutions, regulatory bodies and in- and output markets, can have a significant positive or negative influence on farmers' decision-making, but might be neglected by scientists. 


\section{Rank}
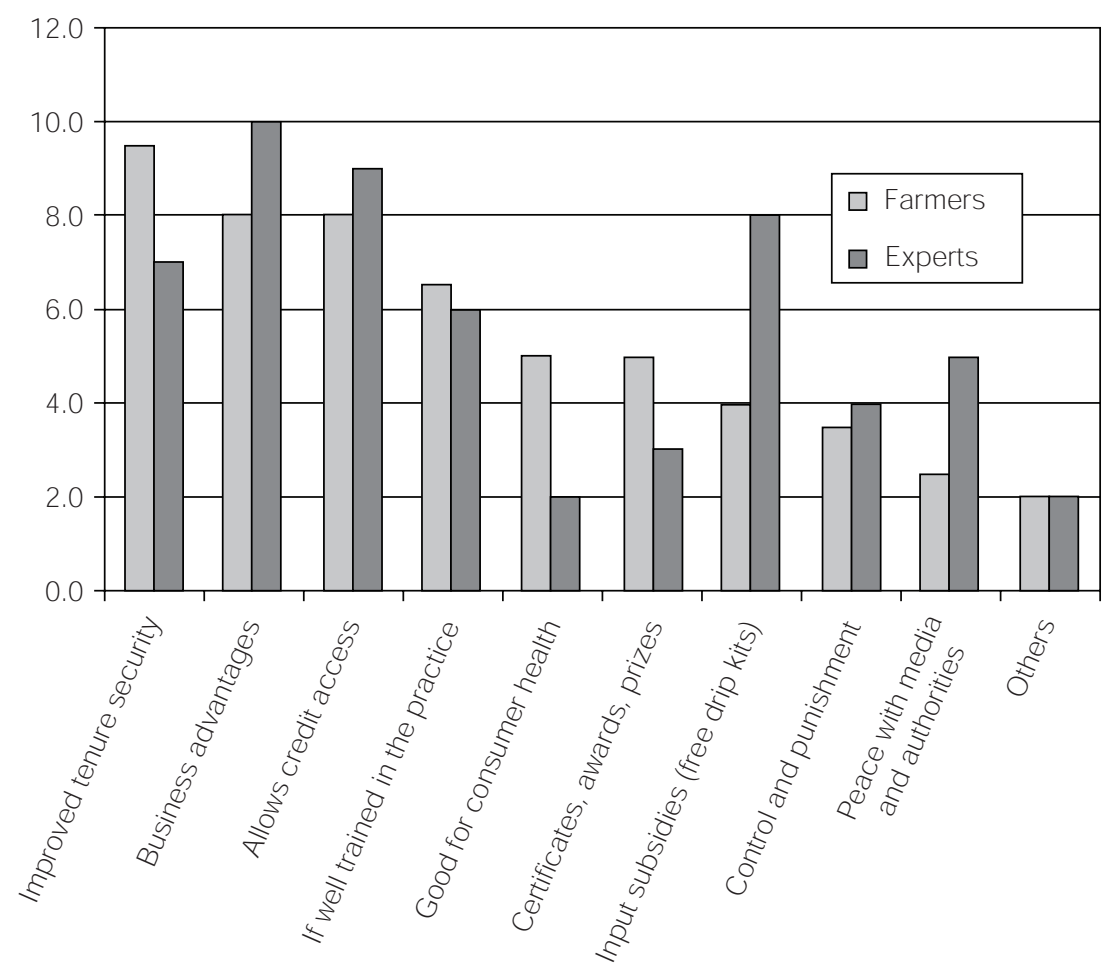

Figure 17.2 Comparing expert opinion with farmer expressed motivation for a possible behaviour change in southern Ghana

Source: IWMI (2008), unpublished

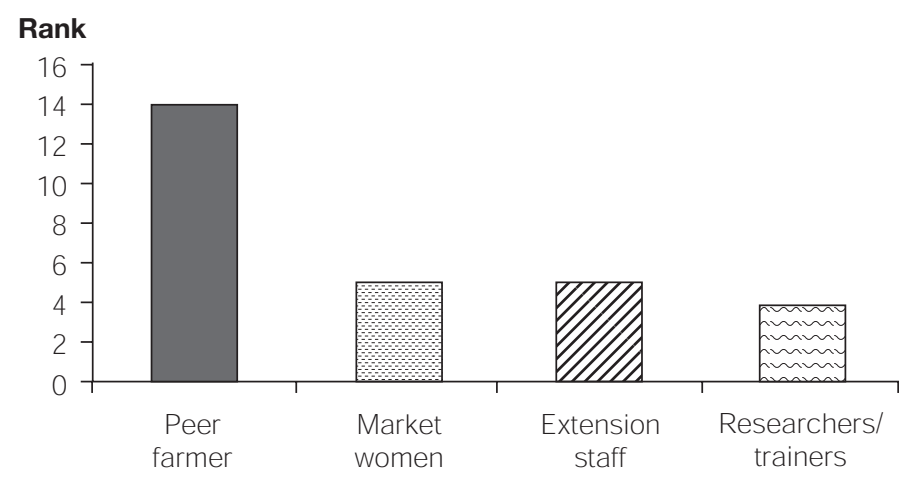

Figure 17.3 Farmers' preferences for which 'person' to follow in teaching innovations in agriculture 


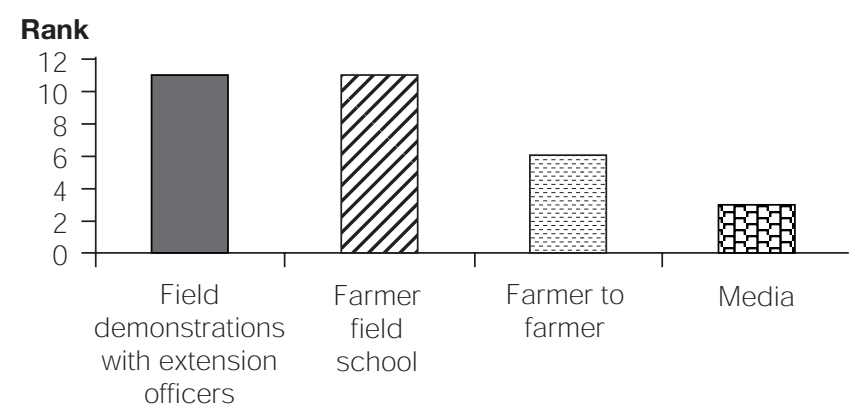

Figure 17.4 Farmers preferences for the method of learning new practices

Source: IWMI (2008), unpublished

\section{Conclusions}

Farmers using wastewater and human excreta are in general not aware of the type of risks they are facing, or do not rank the risk highly. In order to find common ground and to use knowledge to change perceptions and behaviour, farmers and scientists need to work together. The lack of tools and indicators suitable for farmers to assess and monitor health risks is, however, problematic, as the physical indicators used by farmers to assess wastewater and human excreta for reuse do not necessarily correspond to laboratory assessments. It might still be appropriate for researchers to broaden their indicators to include those identified by farmers. These might include problem indicators (poor water quality) and certainly in- and output indicators which cover labour, capital and land inputs, and, most of all, the resulting crop yields.

Recommended practices might have to undergo adjustments to keep efforts low and outputs high. These may not necessarily be the most effective measures in reducing health risks but are probably more sustainable. It is therefore important to encourage farmers to look for solutions on their own, and several indigenous solutions actually reduce health risks even if it is inadvertent (IWMI, 2008).

\section{ACKNOWLEDGEMENT}

Authors wish to thank Line Gram Knudsen and Thilde Rheinländer, both of the Department of International Health, University of Copenhagen, for their contributions towards this paper. 


\section{NoTe}

1 Where exotic vegetables are produced for the market, farmers generally do not consume them and may not be aware of possible health implications from own experience (Drechsel et al., 2006).

\section{REFERENCES}

Avila, M. and Jabbar, M. A. (1992) 'Socio-economic assessment of alley farming', in B. R. Tripathi and P. J. Psychas (eds) The AFNETA Alley Farming Training Manual - Volume 1: Core Course in Alley Farming, Alley Farming Network for Tropical Africa, www.fao. org/Wairdocs/ILRI/x5545E/x5545e09.htm

Bayrau, A., Boelee, E., Drechsel, P. and Dabbert, S. (2009) 'Wastewater use in crop production in peri-urban areas of Addis Ababa: Impacts on health in farm household', Environment and Development Economics (in press)

Binns, J. A., Maconachie, R. A. and Tanko, A. I. (2003) 'Water, land and health in urban and peri-urban food production: The case of Kano, Nigeria', www.cityfarmer.org/ WaterLandHealthKano.rtf

Blumenthal, U. J. and Peasey, A. (2002) 'Critical review of epidemiological evidence of the health effects of wastewater and excreta use in agriculture', unpublished document prepared for World Health Organization, Geneva, www.who.int/water_sanitation_ health/wastewater/whocriticalrev.pdf

Boholm, A. (1998) 'Comparative studies of risk perception: A review of twenty years of research', Journal of Risk Research, vol 1, no 2, pp135-63

Chambers, R. and Ghildyal, B. P. (1985) 'Agricultural research for resource poor farmers: The farmer-first-and-last model', Agricultural Administration, vol 20, pp1-30

Chaudhuri, N. (2008) 'Using participatory education and action research for health risk reduction amongst farmers in Dakar, Senegal', in M. Redwood (ed) Agriculture in Urban Planning: Generating Livelihoods and Food Security, Earthscan/IDRC, London, www.idrc.ca/en/ev-135178-201-1-DO_TOPIC.html

Cofie, O. O., Adeoti, A., Nkansah-Boadu, F. and Awuah, E. (2009) 'Adoption and impacts of excreta use for crop production in southern Ghana', Journal of Environmental Management (under review)

Collinson, M. (2000) 'Evolving typologies for agricultural research and development', in M. Collinson (ed) A History of Farming Systems Research, CABI/FAO, Wallingford, UK, pp 51-8

Dorward, P., Galpin, M. and Shepherd, D. (2003) 'Participatory Farm Management methods for assessing the suitability of potential innovations: A case study on green manuring options for tomato producers in Ghana', Agricultural Systems, vol 75, pp97117

Drechsel, P. S., Graefe, M., Sonou, O. and Cofie, O. (2006) Informal Irrigation in Urban West Africa: An Overview, Research Report 102, IWMI, Colombo, www.iwmi.cgiar. org/Publications/IWMI_Research_Reports/PDF/pub102/RR102.pdf

Drechsel, P. and Gyiele, L. (eds) (1998) 'On-farm research on sustainable land management in sub-Saharan Africa: Approaches, experiences, and lessons', IBSRAM Proceedings 19, Bangkok, p254 
Drechsel, P., Olaleye, A., Adeoti, A., Thiombiano, L., Barry, B. and Vohland, K. (2005) Adoption Driver and Constraints of Resource Conservation Technologies in sub-Saharan Africa, FAO, Humboldt, IWMI University, Accra, Ghana, www.iwmi.cgiar.org/africa/ West/pdf/AdoptionConstraints-Overview.pdf

Gbewonyo, K. (2007) 'Wastewater irrigation and the farmer: Investigating the relation between irrigation water source, farming practices, and farmer health in Accra, Ghana', unpublished thesis, Harvard College, Cambridge, MA

Gerstl, S. (2001) 'The economic costs and impact of home gardening in Ouagadougou, Burkina Faso', PhD dissertation, University of Basel, Basel, Switzerland

IWMI (2008) 'Health risk reduction in a wastewater irrigation system in urban Accra, Ghana', www.youtube.com/watch?v=f_EnUGa_GdM

Keraita, B. (2002) 'Wastewater use in urban and peri-urban vegetable farming in Kumasi, Ghana', unpublished MSc thesis, Wageningen University, Wageningen, The Netherlands

Keraita, B., Drechsel, P. and Konradsen, F. (2008a) 'Perceptions of farmers on health risks and risk reduction measures in wastewater-irrigated urban vegetable farming in Ghana', Journal of Risk Research, vol 11, no 8, pp1047-61

Keraita, B., Jiménez, B. and Drechsel, P. (2008b) 'Extent and implications of agricultural reuse of untreated, partly treated, and diluted wastewater in developing countries', $C A B$ Reviews: Perspectives in Agriculture, Veterinary Science, Nutrition and Natural Resources, CABI Publishing, Wallingford, UK

Keraita, B., Konradsen, F., Drechsel, P. and Abaidoo, R. C. (2007a) 'Effect of low-cost irrigation methods on microbial contamination of lettuce', Tropical Medicine and International Health, vol 12, suppl. 2, pp15-22

Keraita, B., Konradsen, F., Drechsel, P. and Abaidoo, R. C. (2007b) 'Reducing microbial contamination on lettuce by cessation of irrigation before harvesting', Tropical Medicine and International Health, vol 12, suppl. 2, pp8-14

Kilelu, C. (2004) 'Wastewater irrigation and farmer's perception of health risks and institutional perspectives: A case study from Maili Saba, Nairobi', CFP Report 38, IDRC, Ottawa

Knudsen, L. G., Phuc, P. D., Hiep, N. T., Samuelson, H., Jensen, P. K., Dalsgaard, A., Raschid-Sally, L. and Konradsen, F. (2008) 'The fear of awful smell: risk perceptions among farmers in Vietnam using wastewater and human excreta in agriculture', Southeast Asian Journal of Tropical Medicine and Public Health, vol 39, no 2, pp34152

Lazo, J. K., Kinnell, J. C. and Fisher, A. (2000) 'Expert and lay person perceptions of ecosystem risks', Risk Analysis, vol 20, pp179-93

Marenya, P. P. and Barrett, C. B (2007) 'Household-level determinants of adoption of improved natural resources management practices among smallholder farmers in western Kenya', Food Policy, vol 32, pp515-36

Martin, A. and Sherington, J. (1997) 'Participatory research methods - Implementation, effectiveness and institutional context', Agricultural Systems, vol 55, no 2, pp195-216

McGregor, D. A., Thompson, D., Kotei, N., Poku, O. and Simon, D. (2001) 'Testing a method of environmental self-monitoring: Water quality test kit project, peri-urban Kumasi', CEDAR/IRNR Kumasi Paper 2, DFID Peri-urban Interface Production Systems Research Project R7330

Mutsaers, H. J. W., Weber, G. K., Walker, P. and Fischer, N. M. (1997) A Field Guide for On-Farm Experimentation, IITA, Ibadan, Nigeria, p235 
Niang, S. (2002) 'Maitrise des risques dans la valorisation des eaux usées en agriculture urbaine', in O. O. Akinbamijo, S. T. Fall and O. B. Smith (eds) Advances in CropLivestock Integration in West African Cities, International Trypanotolerance Centre, ISRA, IDRC, Ottawa

Obuobie, E., Keraita, B., Danso, G., Amoah, P., Cofie, O., Raschid-Sally, L. and Drechsel, P. (2006) Irrigated Urban Vegetable Production in Ghana: Characteristics, Benefits and Risks, IWMI-RUAF-CPWF, IWMI, Accra, Ghana

Ouedraogo, B. (2002) 'Perceptions of Ouagadougou market gardeners on water, hygiene and disease', Urban Agriculture Magazine, vol 8, pp24-5

Peres, F., Moreira, C. J., Rodrigues, M. and Claudio, L. (2006) 'Risk perception and communication regarding pesticide use in rural work: A case study of Rio de Janeiro State, Brazil', International Journal of Occupational and Environmental Health, vol 12, pp400-407

Rheinländer, T., Olsen, M., Bakang, J. A., Takyi, H., Konradsen, F. and Samuelson, H. (2008) 'Keeping up appearances: Perceptions of street food safety in urban Kumasi, Ghana', Journal of Urban Health, vol 85, no 6, pp952-64

Sanders, D. W., Huszar, P. C., Sombatpanit, S. and Enters, T. (1999) Incentives in Soil Conservation, From Theory to Practice, Oxford \& IBH Publishing, New Delhi

Seidu, R., Drechsel, P. and Stenström, T.-A. (2009) 'Occupational risk associated with the "cake" sludge application in northern Ghana: Comparative assessment of perceived and probabilistic health risk', in preparation

Seidu, R., Heistad, A., Jenssen, P. D., Drechsel, P. and Stenström, T.-A. (2008) 'Quantification of the health risks associated with wastewater reuse in Accra, Ghana: A contribution toward local guidelines', Journal of Water and Health, vol 6, no 4, pp46171

Shingles, K. and Saltori, R. (2008) 'Community use of $\mathrm{H}_{2} \mathrm{~S}$ (hydrogen sulphide) as a verification tool for water safety plans', in H. Jones (ed) Access to Sanitation and Safe Water: Global Partnerships and Local Actions, 33rd WEDC International Conference, Accra, Ghana

Shuval, H. I., Adin, A., Fattal, B., Rawitz, E. and Yekutiel, P. (1986) Wastewater Irrigation in Developing Countries: Health Effects and Technical Solutions, World Bank Technical Paper no 51, World Bank, Washington, DC

Siegrist, M. (2000) 'The influence of trust and perceptions of risks and benefits on the acceptance of gene technology', Risk Analysis, vol 20, pp195-204

Slovic, P. (1987) 'Perception of risk', Science, vol 236, pp280-85

Stewart-Taylor, A. J. and Cherries, J. W. (1998) 'Does risk perception affect behavior and exposure? A pilot study amongst asbestos workers', Annals of Occupational Hygiene, vol 42, pp565-9

Trang, D. T., van der Hoek, W., Tuan, N. D., Cam, P. C., Viet, V. H., Luu, D. D., Konradsen, F. and Dalsgaard, A. (2007) 'Skin disease among farmers using wastewater in rice cultivation in Nam Dinh, Vietnam', Tropical Medicine and International Health, vol 12, no 2, pp51-8

WHO (2006) Guidelines for the Safe Use of Wastewater, Excreta and Greywater, Volume 2: Wastewater Use in Agriculture, World Health Organization, Geneva 